\title{
SISTEM PAKAR MENGIDENTIFIKASI PENYAKIT AYAM BURAS MENGGUNAKAN METODE FORWARD CHAINING (STUDI KASUS : DINAS PETERNAKAN KABUPATEN PASAMAN BARAT) Aulia Mardhatilla'), Julius Santony ${ }^{2)}$,Gunadi Widi Nurcahyo ${ }^{2)}$. \\ ${ }^{1}$ Jl. Raya Lubuk Begalung, Lubuk Begalung Nan XX \\ ${ }^{2}$ Teknoogi Informatika, Fakultas Ilmu Komputer, Universitas Putra Indonesia "YPTK" Padang \\ ${ }^{3}$ Fakultas Ilmu Komputer, Universitas Putra Indonesia "YPTK" Padang e-mail: aulyamardhatillah@gmail.com ${ }^{1}$
}

\begin{abstract}
Expert system (Artifical Intelligence) is a computer-based application that is used to solve problems as thought by experts, one of the applications of expert systems is in identifying chicken diseases. The reduced production of chicken eggs is influenced by several factors including age, season, disease, and maintenance system. The lack of knowledge about the disease and the distribution of veterinarians is not evenly distributed, then we need a system that can provide recommendations about free-range chicken disease. Data on free-range chicken disease processed in this study were sourced from the Dinas Peternakan Kabupaten Pasaman Barat.
\end{abstract}

Keywords: Expert System, Chicken Disease, Dinas Peternakan kabupaten Pasaman Barat, Forward Chaining

\begin{abstract}
Abstrak
Sistem pakar (Artifical Intelligence) merupakan aplikasi berbasis komputer yang digunakan untuk menyelesaikan masalah sebagaimana yang dipikirkan oleh para pakar, salah satu penerapan sistem pakar adalah dalam mengidentifikasi penyakit ayam. Menurunnya produksi telur ayam dipengaruhi oleh beberapa faktor diantaranya umur, musim, penyakit, dan sistem pemeliharaan. Minimnya pengetahuan tentang penyakit dan penyebaran dokter hewan yang tidak merata, maka diperlukan suatu sistem yang dapat memberikan rekomendasi tentang penyakit ayam buras. Data penyakit ayam buras yang diolah dalam penelitian ini bersumber dari Dinas Peternakan Kabupaten Pasaman Barat.
\end{abstract}

Kata Kunci: Sistem Pakar, Penyakit ayam, Dinas Peternakan kabupaten Pasaman Barat, Forward Chaining

\section{PENDAHULUAN}
Menurunnya produksi telur ayam dipengaruhi oleh beberapa faktor diantaranya umur, musim, penyakit, dan sistem pemeliharaan. Minimnya pengetahuan tentang penyakit dan penyebaran dokter hewan yang tidak merata, maka diperlukan suatu sistem yang dapat memberikan rekomendasi tentang penyakit ayam buras. Data penyakit ayam buras yang diolah dalam penelitian ini bersumber dari Dinas Peternakan Kabupaten Pasaman Barat. Dari data yang diolah menggunakan metode forward chaining nantinya dapat membantu pengguna dalam menangani penyakit yang sedang menyerang ayam, sehingga dapat membantu dalam pencegahan serta mampu membantu permasalahan peternak di daerah ketika

dokter atau ahli terbatas secara tepat. maka penulis akan melakukan penelitian pada Dinas Peternakan Kab. Pasaman Barat, dengan menerapkan sistem pakar dalam mengidentifikasi penyakit ayam buras menggunakan metode Forward Chaining. Sehingga dapat menjadi solusi dalam pengambilan keputusan yang cepat dan tepat.

\section{TINJAUAN PUSTAKA}

\subsection{Sistem Pakar}

Sistem pakar merupakan sebuah sistem yang berbasis komputer dengan menggunakan teknik penelaran, pengetahuan dan fakta dalam memecahkan suatu masalah yang biasanya hanya dapat dipecahkan oleh seorang pakar dalam bidang tertentu (Sri Ngudi Wahyuni, 2019). 


\subsection{Forward Chaining}

Metode Forward Chaining merupakan salah satu metode yang dapat digunakan dalam proses sistem berbasis pengetahuan untuk menghasilkan informasi baru dari informasi yang sudah diketahui. Pendekatan metode Forward Chaining menggunakan proses pengurutan yang dimulai dengan menampilkan kumpulan data atu fakta dilapangan kemudian diproses untuk mendapatkan kesimpulan akhir. (Harjanto et al., 2018).

Tahapan yang harus dilakukan dalam membuat Forward Chaining, yaitu:

1. Mempersiapkan data input

2. Menentukan tabel keputusan pakar

3. Menentukan rule berdasarkan data yang diperoleh

4. Melakukan proses pelacakan

\subsection{Penyakit Ayam Buras}

Penyakit pada ayam secara umum terbagi menjadi penyakit infeksi dan penyakit non infeksi. Penyakit infeksi adalah penyakit yang disebabkan oleh virus, bakteri, mikal, dan parasit. Selain penyakit non infeksi adalah penyakit yang disebabkan oleh definisi nutrisi, vitamin mineral dan keracunan.

Penyakit pada ayam adakalanya menyebar dan menular dengan sangat cepat dengan tingkat kematian yang tinggu, misalnya penyakit yang disebabkan oleh mikrob.

\section{METODE PENELITIAN}

Metode penelitian merupakan rancangan dari kegiatan penelitian yang dilakukan dalam mencari, merumuskan dan menganalisa hingga dapat menyusun sesuai dengan langkah-langkah yang akan digunakan dan waktu yang digunakan sebagai acuan dalam memperoleh dalam analisa data.

Agar penelitian berjalan dengan teratur maka diperlukan sebuah kerangka penelitian. Adapun kerangka penelitian dapat dilihat pada gambar 3.1.

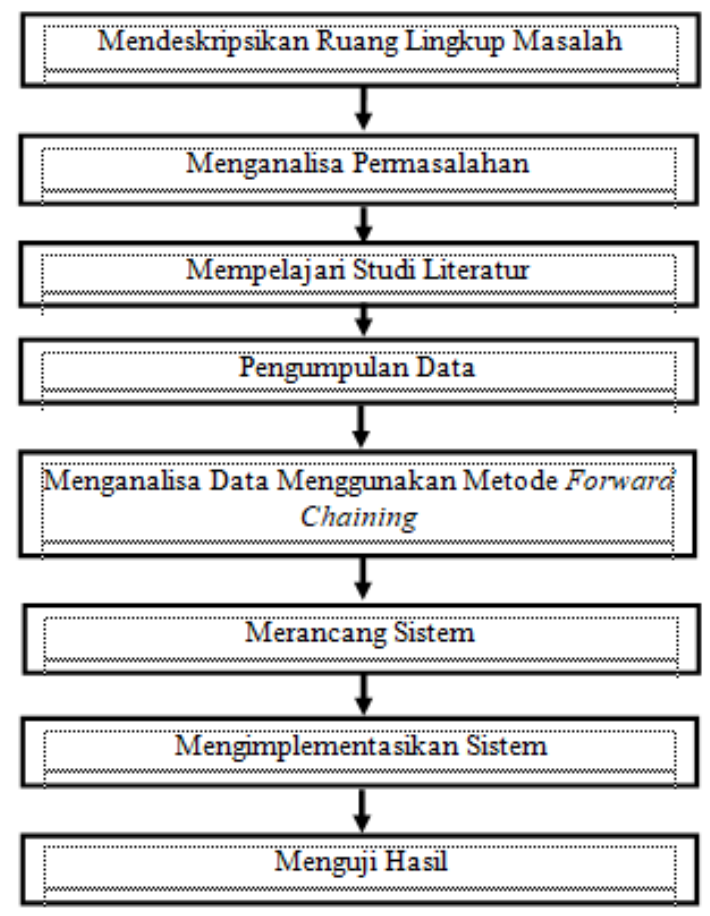

Gambar 3.1 Kerangka Kerja

Adapun penjelasan kerangka kerja yang dilakukan adalah:

1. Mendeskripsikan Ruang Lingkup Masalah Ruang lingkup masalah yang akan diteliti harus ditentukan terlebih dahulu, agar mampu menjelaskan dan menentukan ruang lingkup yang akan diteliti. Jadi mendeskripsikan ruang lingkup masalah ini merupakan langkah awal dalam melakukan penulisan ini.

2. Menganalisa Permasalahan

Menganalisa permasalahan merupakan alur berikutnya agar penelitian yang akan dilakukan dapat memahami masalah yang telah ditentuakan batasan masalahnya. Diharapkan dengan masalah yang telah ditentukan dapat menganlisa tersebut dengan baik.

3. Mempelajari Literatur

Dengan memepelajari literatur maka penelitian yang dilakukan tidak mengada ada sehingga penelian tersebut nantinya dapat diterima di dunia ilmu pengetahuan dan masyarakat umum. Adapun kegiatan studi literatur yang lakukan dalam penenlitian ini sebagai berikut:
a. Observasi
b. Wawancara
c. Study literatur

4. Pengumpulan Data

Mengumpulkan data dilakukan dengan cara observasi dan wawancara terhadap dokter hewa 
yang bekerja pada Dinas Peternakan kabupaten Pasaman Barat.

5. Menganalisa Data Menggunakan Metode Forward Chaining

Agar permalahan penelitian ini dapat dianalisa maka digunakan metode Forward Chaining, dengan harapan mendapatkan gejala penyakit, jenis penyakit, penyebab dan solusi untuk mengatasi penyakit ayam buras.

6. Merancang Sistem

Pada tahapan ini nantinya akan menghasilkan sebuah sistem yang dapat digunakan untuk memproses analisa penelitian secara terkomputerisasi.

7. Mengimplementasi sistem

Sistem ini dirancang menggunakn bahasa bahasa pemrograman Visual Basic.Net yang menerapkan metode Forward Chaining. Implementasi ini dilakukan untuk membandingkan hasil yang didapatkan dengan analisa secara manual dengan sistem.

8. Hasil pengujian

Pada tahap ini dilakukan pengujian terhadap sistem yang telah dirancang agar dapat digunakan secara maksimal.

\section{HASIL DAN PEMBAHASAN}

Tahapan analisa dan perancangan sistem sangat diperlukan, hal pertama yang harus dilakukan adalah melakukan analisa sistem. Analisa sangat penting digunakan dalam menyelesaikan suatu permasalahan. Untuk memudahkan dalam analisa perancangan sistem maka dibuat bagan alir analisa perancangan seperti pada gambar 4.1 dibawah ini :

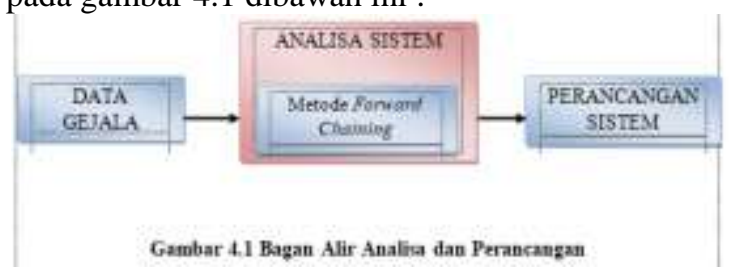

Data yang digunakan pada penelitian ini adalah data gejala, jenis penyakit, dan solusi dari penyakit ayam buras pada Dinas Peternakan Kabupaten Pasaman Barat. Data didapatkan dengan cara wawancara langsung dengan pakar. Dapat dilihat pada tabel 1 berikut :

Tabel 1. Data Gejala Penyakit Ayam Buras

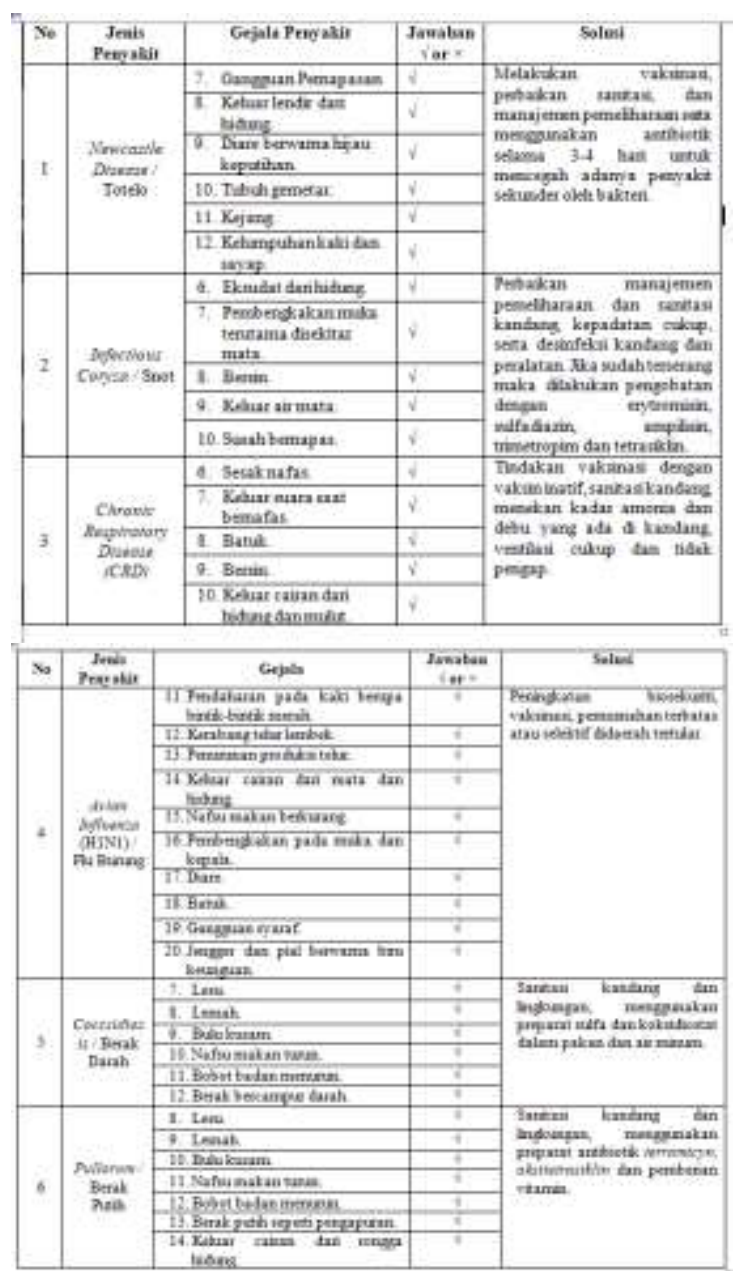

Adapun tahapan-tahapan dalam penyusunan rule berdasarkan metode forward chaining sebagai berikut:

1. Mempersiapkan data input

Data yang diperlukan berupa data gejala, jenis gejala serta solusi yang diusulkan seperti pada tabel berikut:

a. Tabel gejala penyakit 


\begin{tabular}{|c|c|}
\hline Kare & Cejnin \\
\hline का & 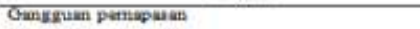 \\
\hline CO2 & Koluar tendir dar bidung \\
\hline $\cos 3$ & 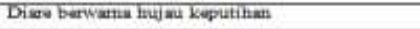 \\
\hline क्यक & Twboth gemetor \\
\hline 005 & Kajumb \\
\hline 000 & Kelumpothan kasa dan raysp \\
\hline का & 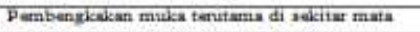 \\
\hline क्रश & Benin \\
\hline 000 & Kalinat air mata \\
\hline क्णा० & Reluar vian iast bemifing \\
\hline कor1 & Eatuk: \\
\hline $\cos 2$ & Reluar caifan dari mutut \\
\hline कor & Kaluar cairan dari bichimg \\
\hline $\cos 14$ & Pendarahan pada kas berups bintik-bintik merah \\
\hline Cols & Demirimaiti produsat telut \\
\hline $\operatorname{col} 6$ & Kerabang tolur lerrber: \\
\hline 6017 & 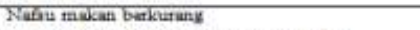 \\
\hline क्राह & Tenge or dan pial berwarna biru kmunguan \\
\hline ब्रा० & Lamiah \\
\hline कर20 & Bसका Kunam \\
\hline 0021 & Bobot badan mamurin \\
\hline काश & Berak bercampur darah \\
\hline 6023 & Earak putilh seperti peanifapuran \\
\hline क्र24 & Lent \\
\hline 0025 & Karuatian Mandadak \\
\hline Co2, & Gangenan syaref \\
\hline C02 2 & 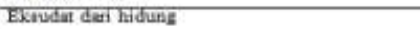 \\
\hline
\end{tabular}

\section{b. Tabel penyakit}

\begin{tabular}{|c|c|}
\hline Kode & Jeais Penyakit \\
\hline P01 & Nownatio Direose / Totelo \\
\hline 902 & hagoctibus Cansa / Snot \\
\hline $\mathrm{P} 03$ & 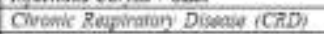 \\
\hline P04 & 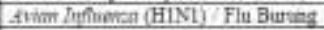 \\
\hline P05 & Coessimosit / Betak Danh \\
\hline 806 & Fullorniv / Bersl Purh \\
\hline
\end{tabular}

2. Menentukan tabel keputusan pakar

Membuat tabel keputusan pakar yang bertujuan untuk dapat mengetahui penyakit dari gejala yang ada sehingga mudah dalam membuat rule dapat dilihat pada tabel berikut:

\begin{tabular}{|c|c|c|c|c|c|c|c|}
\hline \multirow{2}{*}{ Kode } & \multirow{2}{*}{ Gejnla } & \multicolumn{6}{|c|}{ Penyalit } \\
\hline & & $\mathrm{P} 01$ & $\mathrm{P} 02$ & P03 & P04 & P05 & P06 \\
\hline $\mathrm{G} 01$ & Gangzuan pemapasan & $\nabla$ & $\checkmark$ & $\checkmark$ & & & \\
\hline $\mathrm{G} 02$ & Keluar lendir dari hidung & $\checkmark$ & & & & & \\
\hline G03 & Diare berwama hujau keputihan & $\checkmark$ & & & & & \\
\hline G04 & Tubuh gemetar & $\checkmark$ & & & & & \\
\hline G05 & Kejang & $\checkmark$ & & & & & \\
\hline G06 & \begin{tabular}{|l|} 
Kelumpuhan kaki dan sayap \\
\end{tabular} & $\checkmark$ & & & & & \\
\hline G07 & $\begin{array}{l}\text { Pembengkakan muka terutama di } \\
\text { sekitar mata }\end{array}$ & & $\sqrt{ }$ & & & & \\
\hline G08 & Bersin & & 5 & $\checkmark$ & & & \\
\hline G09 & Keluar air mata & & $\sqrt{ }$ & & & & \\
\hline G010 & Keluar suara saat bemafas & & & $\checkmark$ & & & \\
\hline G011 & Batuk & & & $\sqrt{ }$ & & & \\
\hline G012 & Keluar cairan dari mulut & & & $\sqrt{ }$ & & & \\
\hline $\mathrm{G} 013$ & Keluar cairan dari hidung & & & $\checkmark$ & & & \\
\hline G014 & $\begin{array}{l}\text { Pendarahan pada kaki benupa bintik- } \\
\text { bintik merah }\end{array}$ & & & & $\checkmark$ & & \\
\hline G015 & Penurunan produksi telur & & & & 8 & & \\
\hline G016 & Kerabang telur lembek & & & & $\checkmark$ & & \\
\hline G017 & Nafsu makan berkurang & & & & $\checkmark$ & $\checkmark$ & $\checkmark$ \\
\hline G018 & $\begin{array}{l}\text { Jengger dan pial berwama biru } \\
\text { keunguan }\end{array}$ & & & & $\checkmark$ & & \\
\hline G019 & Lemah & & & & & $\checkmark$ & $\sqrt{1}$ \\
\hline G020 & Bulu kusam & & & & & $\checkmark$ & $\checkmark$ \\
\hline G021 & Bobot badan menurun & & & & & $\checkmark$ & $\sqrt{ }$ \\
\hline G022 & Berak bercampur darah & & & & & $\sqrt{ }$ & \\
\hline G023 & Berak putih seperti pengapuran & & & & & & $\checkmark$ \\
\hline G024 & Lesu & & & & & $\checkmark$ & $\sqrt{ }$ \\
\hline G025 & Kematian Mendadak: & & & & $\checkmark$ & & \\
\hline G026 & Gangguan Syaraf & & & & $\checkmark$ & & \\
\hline G027 & Eksudat dari hidung & & $\sqrt{ }$ & & & & \\
\hline
\end{tabular}

3. Menentukan rule berdasarkan data yang didapat Menentukan sebuah aturan atau rule dilakukan untuk dpat melakukan proses pelacakan dengan metode Forward Chaining. Rule yang terbentuk dapat dilihat pada tabel berikut:

\begin{tabular}{|c|l|}
\hline No & \multicolumn{1}{|c|}{ Rule } \\
\hline 1 & $\begin{array}{l}\text { IF G01 is true AND G02 is true AND G03 is true AND } \\
\mathrm{G} 04 \text { is true AND G05 is true AND G06 THEN P01 }\end{array}$ \\
\hline 2 & $\begin{array}{l}\text { IF G01 is true AND G07 is true AND G08 is true AND } \\
\mathrm{G} 09 \text { is true AND G027 THEN P02 }\end{array}$ \\
\hline 3 & $\begin{array}{l}\text { IF G01 is true AND G08 is true AND G010 is true } \\
\text { AND G011 is true AND G012 is true AND G013 THEN } \\
\mathrm{P03}\end{array}$ \\
\hline 4 & $\begin{array}{l}\text { IF G014 is true AND G015 is true AND G016 is true } \\
\text { AND G017 is true AND G018 is true AND G025 is true } \\
\text { AND G026 THEN P04 }\end{array}$ \\
\hline 5 & $\begin{array}{l}\text { IF G017 is true AND G019 is true AND G020 is true } \\
\text { AND G021 is true AND G022 is true AND G024 THEN } \\
\mathrm{P05}\end{array}$ \\
\hline 6 & $\begin{array}{l}\text { IF G017 is true AND G019 is true AND G020 is true } \\
\text { AND G021 is true AND G023 is true AND G024 THEN } \\
\mathrm{P06}\end{array}$ \\
\hline
\end{tabular}

4. Membuat pohon keputusan

Pohon keputusan di bawah ini merupakan proses pengambilan keputusan berdasarkan kemunculann gejala penyakit pada ayam buras. 


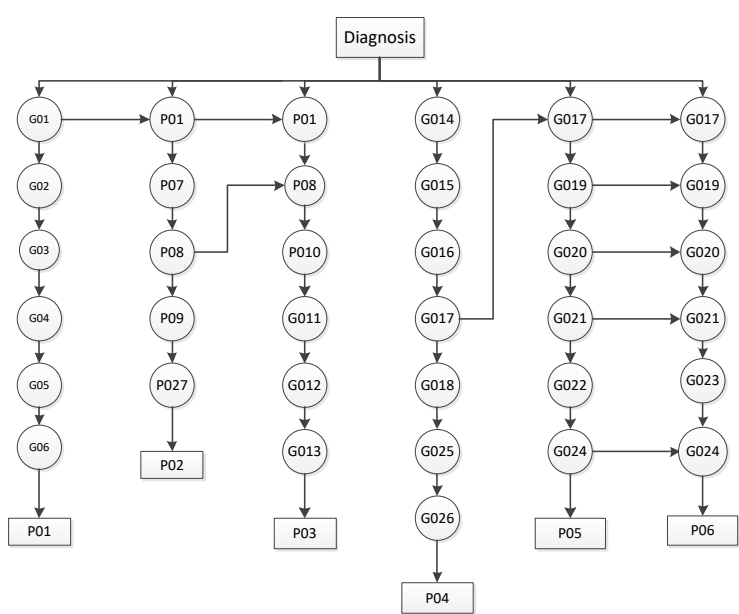

5. Hasil penelusuran diagnosa penyakit

Dari pohon keputusan yang terbentuk maka dapat disimpulkan hasil penelusuran diagnosis gejala penyakit ayam buras dalam tabel berikut:

\begin{tabular}{|l|l|l|}
\hline No & \multicolumn{1}{|c|}{ Gejala } & Penyakit \\
\hline 1 & $\begin{array}{l}\text { G01, G02, G03, G04, G05, } \\
\text { G06 }\end{array}$ & P01 \\
\hline 2 & G01, G07, G08, G09, G027 & P02 \\
\hline 3 & $\begin{array}{l}\text { G01, G08, G010, G011, G012, } \\
\text { G013 }\end{array}$ & P03 \\
\hline 4 & $\begin{array}{l}\text { G014, G015, G016, G017, } \\
\text { G018, G025, G026 }\end{array}$ & P04 \\
\hline 5 & $\begin{array}{l}\text { G017, G019, G020, G021, } \\
\text { G022, G024 }\end{array}$ & P05 \\
\hline 6 & $\begin{array}{l}\text { G017, G019, G020, G021, } \\
\text { G023, G024 }\end{array}$ & P06 \\
\hline
\end{tabular}

\section{Implementasi Sistem}

Implementasi sistem merupakan proses yang dilakukan untuk mengetahui suatu sistem yang telah dirancang dan dibangun dapat digunakan oleh pengguna.

\section{Tampilan Halaman}

\section{Menu Utama}

Rancangan menu merupakan sebuah tampilan yang dirancang sebagai tempat untuk menampilkan menu-menu yang tersedia di dalam sistem. Dapat dilihat pada gambar berikut :

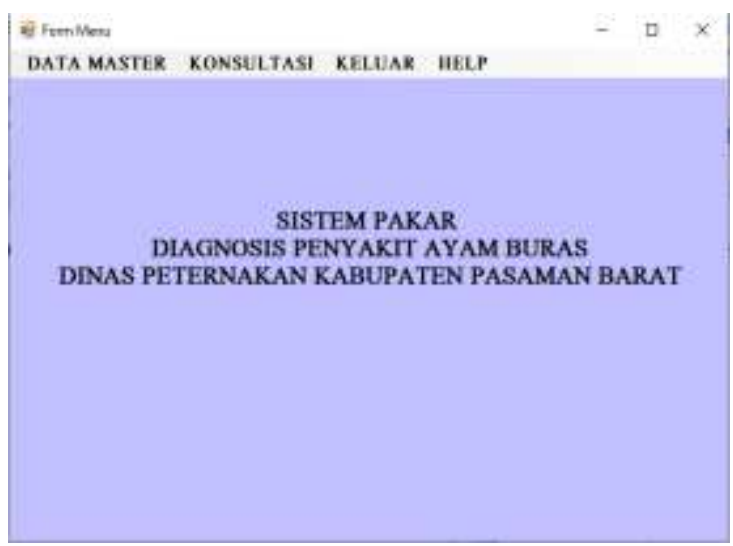

\section{Tampilan Halaman Konsultasi}

Dalam menu konsultasi, user hanya memilih gejala yang sesuai pada layar monitor, kemudian menetak tombol proses. Sebagai output nya akan tampil kemungkina diagnosa dan solusi yan diperlukan. Dapat dilihat pada gambar di bawah berikut:

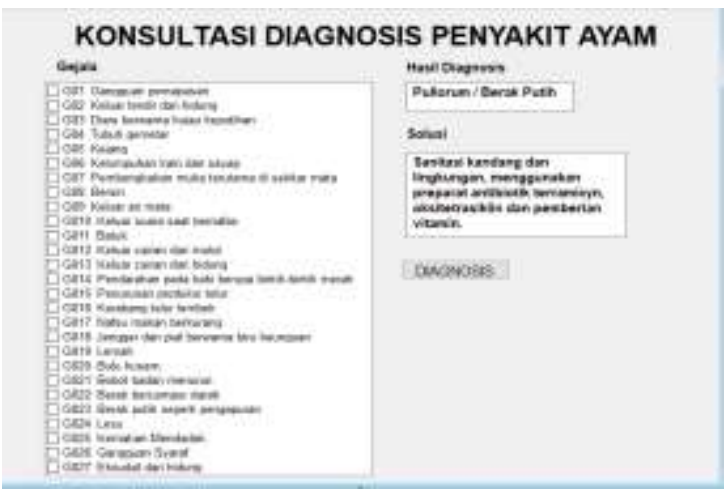

\section{KESIMPULAN}

Berdasarkan analisa dari sistem pakar diagnosa penyakit ayam buras ini dapat ditarik kesimpulan sebagai berikut:

1. Aplikasi Sistem Pakar Mengidentifikasi Penyakit Ayam Buras digunakan untuk mempercepat pencarian dan pengaksesan terhadap ilmu pengetahuan oleh masyarakat yang membutuhkan informasi penyakit ayam .

2. Hasil pengujian Sistem Pakar Mengidentifikasi Penyakit Ayam Buras menunjukkan bahwa Sistem Pakar ini dapat melakukan penambahan data penyakit, data gejala, serta solusi.

3. Aplikasi Sistem Pakar yang telah dibangun dapat melakukan identifikasi terhadap penyakit ayam buras secara tepat dan akurat dengan tingkat akurasi sebesar sebesar 83,33\% dari 6 data pengujian yang didapat dari pendapat 
pakar dengan membandingkan kasus yang sama pada sistem.

\section{DAFTAR PUSTAKA}

[1] Amin, R., Pitriani, P., \& Informatika STMIK Nusa Mandiri Jakarta wwwnusamandiriacid, T. (2018). PENERAPAN METODE FORWARD CHAINING UNTUK DIAGNOSA PENYAKIT INSOMNIA. Maret, 14(1), 97. www.nusamandiri.ac.id

[2] Fauzi, M. (2018). Sistem Pakar Mendeteksi Kerusakan Keyboard Menggunakan Metode Forward Chaining. Jurnal Sistem Informasi Kaputama (JSIK), 2(1), 96-101.

[3] Hidayatulloh, I., \& Yogyakarta, U. N. (2018). Implementasi Metode Forward Chaining Untuk Mendeteksi Penyakit Pada Tanaman Kelengkeng. Jurnal Mantik Penusa Is Licensed under a Creative Commons Attribution-NonCommercial 4.0 International License (CC BY-NC 4.0), 11(May), 14-21.

[4] Harjanto, A., Karnila, S., \& Nugraha, F. (2018). Rancang Bangun Aplikasi Sistem Pakar Untuk Konsultasi Perilaku Siswa Di Sekolah Menggunakan Metode Forward Chaining. Simetris: Jurnal Teknik Mesin, Elektro Dan Ilmu Komputer, 9(2), 817-824. https://doi.org/10.24176/simet.v9i2.2367

[5] Husin, A., Usman, \& Faren, M. P. (2018). Sistem Pakar Pendeteksi Penyakit Berdasarkan Keluhan Buang Air Kecil. JURNAL IPTEK TERAPAN Research of Applied Science and Education, 4, 277-285.

[6] Kurniawan, A. (2018). Sistem Pakar Mendiagnosa Penyakit Flu Burung Secara ONLINE DENGAN METODE FORWARD CHAINING. Kurniawan, A. (2018). Sistem Pakar Mendiagnosa Penyakit Flu Burung Secara ONLINE DENGAN METODE FORWARD CHAINING. 33-39., 33-39.

[7] Mawaddah, U., \& Fauzi, M. (2018). SISTEM PENDUKUNG KEPUTUSAN UNTUK MENENTUKAN DOSIS OBAT PADA ANAK MENGGUNAKAN METODE FORWARD CHAINING (Studi Kasus Di Klinik Dokter Umum Karanggayam Srengat). Antivirus: Jurnal Ilmiah Teknik Informatika, 12(1), 1-10. https://doi.org/10.35457/antivirus.v12i1.440

[8] Nurajizah, S., \& Saputra, M. (2018). Sistem Pakar Berbasis Android Untuk Diagnosa Penyakit Kulit Kucing Dengan Metode Forward Chaining. None, 14(1), 7-14.

[9] Solihah, I., Gunawan, A., \& Supiandi, A.
(2013). Sistem Pakar Diagnosa Penyakit Ayam Berbasis Mobile Computing Menggunakan Metode Inferensi. Konferensi Nasional Ilmu Sosial \& Teknologi (KNIST), 1(1), 22-27.

[10] Ritonga, M. R., Solikhun, S., Lubis, M. R., \& Windarto, A. P. (2018). Sistem Pakar Diagnosa Gejala Awal Penyakit Akibat Virus Pada Anak Berbasis Mobile Dengan Forward Chaining. InfoTekJar (Jurnal Nasional Informatika Dan Teknologi Jaringan), 2(2), 140-145.

https://doi.org/10.30743/infotekjar.v2i2.298

[11] Syawitri, A., Defit, S., \& Nurcahyo, G. W. (2018). Diagnosis Penyakit Gigi dan Mulut Dengan Metode Forward Chaining. Jurnal Sains, Teknologi Dan Industri, 16(1), 24-29.

[12] Suhardi, I., Haryoko, S., \& Jaya, H. (2016). Pengembangan sistem pakar menggunakan Metode Forward Chaining untuk penelusuran dan publikasi manuskrip ilmiah pada Jurnal Internasional Bereputasi. Prosiding Seminar Nasional Lembaga Penelitian Universitas Negeri Makassar.

[13] Trianto, J. (2018). Penerapan Metode Forward Chaining untuk Diagnosa Penyakit Diare pada Anak Usia 3-5 Tahun Berbasis Mobile Android. Jurnal Informatika Universitas Pamulang, 3(2), 98. https://doi.org/10.32493/informatika.v3i2.152 0

[14] Yanto, B. F., Werdiningsih, I., \& Purwanti, E. (2017). Aplikasi Sistem Pakar Diagnosa Penyakit Pada Anak Bawah Lima Tahun Menggunakan Metode Forward Chaining. Journal of Information Systems Engineering and Business Intelligence, 3(1), 61. https://doi.org/10.20473/jisebi.3.1.61-67.

[15] S. Sularno and P. Anggraini, "PENERAPAN ALGORITMA C4.5 UNTUK KLASIFIKASI TINGKAT KEGANASAN HAMA PADA TANAMAN PADI (Studi Kasus : Dinas Pertanian Kabupaten Kerinci)," J. Sains dan Inform., vol. 3, no. 2, p. 161, Nov. 2017. 